\title{
アルコキシドの加水分解法による単分散微粒子の合成
}

\section{Preparation of Monodispersed Fine Particles by Hydrolysis of Metal Alkoxides}

水 谷 惟 恭*

Nobuyasu MIZUTANI

Key Words: Alkoxide, Hydrolysis, Monodispersed Particle, Fine Particle

1.はじめに

セラミック焼結体は粉を焼き固めて作られる。セラ ミックス原料粉体は所望の寸法と性能をあつセラミ ックスを作るために非常に重要な意味をむつ。セラ ミックスは製造工程で発生したキズやクラックなど の欠陥をその後の工程で除くことは困難である。言 い換えると，原料の欠点は最後まで残ることである。 こてまで断言するのには異論はあろうが, 原料の重要 性は十分認められるとてろである。ガラスのように原 料を一度高温で十分溶融する場合には原料粉体の形や 粒径は工程にそれほよ゙影響を与えないが，焼結体のよ うに原料粒子の形が保持されながら，粒子の結合が起 こる場合には，粒形や粒径などは工程や製品に大きな 影響を与える。

さて，どのような粉体がセラミックス原料として良 いのか。たとえば以下のような性能をもつ焼結体を作 製したいとしよう。

(1)焼結温度が低い

(2)ち密化する。残留気孔がない

(3) 寸法精度がよい

(4)焼結体の粒径分布が狭く，なおかつ粒径が小さい

昭和63年10月 12 日受付

* 東京工業大学無機材料工学科 ( $\mathbf{T} 152$ 目黒区大岡山 $2-12-1$ )

TEL 03-726-1111 内線 2519

〈著者紹介〉

昭和 45 年東京工業大学大学院博士課程修了。東京工業大学工学部 無機材料工学科助手, 助教授を経て, 昭和62年から東京工業大学 教授

専門 : 機能セラミックス, 特にセラミックスプロセシング(超微粉末, 単結晶, 薄膜, 焼結体), 粒界現象に関係した電気的性質や 液相焼結, X線分析や電子顕微鏡による状態分析など。
ての場合に望ましい粉体特性は現在十分に明らかに されていない。例えば，(4)の条件は原料粉体の粒径お よび粒径分布に影響される。(3)は多分成形密度に関係 している。なるべく密充填した成形体の方がよい。さ て, (1)と(2)の条件に対する答が難しい。焼結の駆動力 は表面エネルギーの減少であり，具体的には系全体の 表面積の減少である。粒子の小さい方が駆動力が大き い。ところが焼結現象は一般には原子やイオンの拡散 で起こる。低温では拡散係数は小さく, また表面拡散 が優勢になる。このように，極端に低温での焼結はい くら粒子を小さくしてあ現実には起てりにくいし，ま た真のち密化も難しい。さらに，粒子が小さくなると 充填密度が上がらなくなったり，凝集が起こりやすく なる。図111はこのような粒子径と焼結性やハンドリ ング性の関係をやや概念的に示したものである。

例えば粒径の小さな粒子が疑集してある大きさの粒 からなる粉末を焼結すると, 最初に小さな粒子間で焼 結が起てり, ややち密な凝集粒子となる。そして次に ての大きな凝集粒子間の焼結へと進むが，乙の粒はか なり大きいので, 表面エネルギーを減少させて, 互い に焼結するのが困難となる。すなわち, この場合, 焼 結前に小さな粒子を凝集から開放して, 一個一個が独 立に焼結できるようにしておくことが必要となる。

また，沈殿などの方法で作った粒子には無定形や非 晶質のあのが多い。非晶質の方が結晶質のあのより密 度が小さい。てのような粒子を成形して焼結すると粒 子間の結合以前に, 各々の粒子の結晶化が起てって粒 子が収縮すると, 粒子間に隙間ができ, 焼結は逆に起 てりにくくなってしまう。

てのようにセラミックス用粉体を一つ採り上げても 


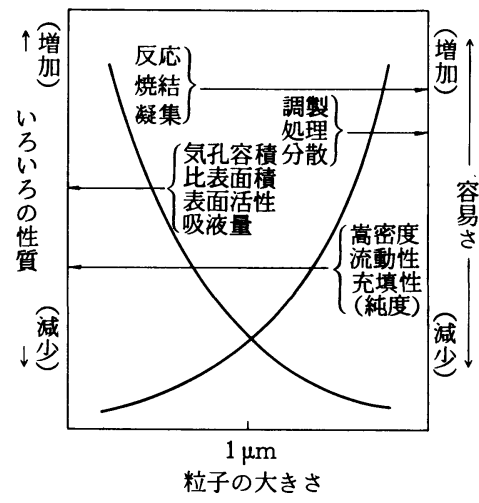

図 1 粉体の諸性質と粒子の大きさとの関係。粒子の大きさが， いろいろの操作，現象および性質に異なった寄与を示す ことを概念的に示す1)。

望ましい粉の条件の確立は難しい。しかし，てれまで のセラミックスの経験から次のような条件が望ましい とされている。

(1)粒子が球形である

(2)粒子の大きさが $1 \mu \mathrm{m}$ 以下であって，粒径分布が 狭い

(3)凝集していない

(4)種々の結晶形をあつ粒子が含まれてなく，単一の 結晶形から成る

(5)高純度である

てのような条件をそなえた粒子としては，例えば単
分散コロイド粒子がある。本稿では単分散コロイド粒 子について述べる。

\section{2. 単分散粒子}

単分散と対をなす言葉が多分散である。図 2 は単 分散粒子，多分散粒子そして凝集粒子を模式的に示し た。単分散に相当する用語として論文等でよくみかけ るのは Monodispersed, Monosize, Narrow-size, Uniformなどである。いずれあ粒径分布が非常に狭い ことを表わしている。より厳密に単分散粒子を言うと きには粒子の大きさだけでなく, 組成や結晶構造など までが同一である場合を指す。さて, 粒径の分布では幾 何標準偏差 $\left(\sigma_{\mathrm{g}}\right)$ を用いて表わすが, 単分散粒子の $\sigma_{\mathrm{g}}$ が定義 されていないので, 通常 $\sigma_{\mathrm{g}}<1.2$ としている場合が多い。 しかし $\sigma_{\mathrm{g}}$ が 1.2 ではやや分布が広く，やはり，1.1以 下にならないと分布が狭いという感触はうけない。後

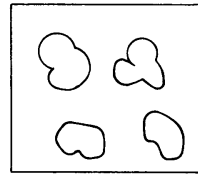

Agglomerated

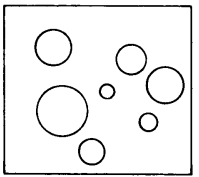

Polydispersed

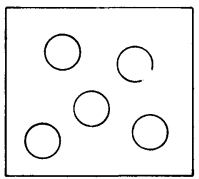

Monodispersed Monosize Narrow-size Uniform $\sigma_{\boldsymbol{g}}<1.2$
図 2 単分散と多分散

表 1 単分散コロイドの合成法

\begin{tabular}{|c|c|c|c|c|}
\hline \multicolumn{2}{|c|}{ 反 応 相 } & 合 成 法 & 概 要 · 特 徵 & 合 成 例 \\
\hline \multicolumn{2}{|c|}{ 気 } & エアロゾル法 & $\begin{array}{l}\text { 金属アルコキシド, 塩化物のエア } \\
\text { ロゾルを加水分解 }\end{array}$ & $\mathrm{TiO}_{2}, \mathrm{Al}_{2} \mathrm{O}_{3}$ \\
\hline \multirow{10}{*}{ 液相 } & \multirow{6}{*}{ 均一系 } & $\begin{array}{l}\text { 金属塩溶液の加水分解法 } \\
\text { (Forced hydrolysis) }\end{array}$ & $\begin{array}{l}\text { 酸性・高温条件下で金属塩溶液を } \\
\text { 熟成 }\end{array}$ & $\begin{array}{l}\mathrm{Cr}(\mathrm{OH})_{3}, \mathrm{TiO}_{2} \\
\alpha-\mathrm{Fe}_{2} \mathrm{O}_{3}, \alpha-\mathrm{AIOOH}\end{array}$ \\
\hline & & アルコキシド法 & $\begin{array}{l}\text { 金属アルコキシドをアルコール中 } \\
\text { で加水分解 }\end{array}$ & $\mathrm{SiO}_{2}, \mathrm{TiO}_{2}, \mathrm{ZrO}_{2}$ \\
\hline & & 酸化還元法 & $\begin{array}{l}\text { 金属塩溶液の酸化, 還元. 主とし } \\
\text { て金属の合成に用いられる }\end{array}$ & $\mathrm{Au}, \mathrm{Ag}, \mathrm{Se}$ \\
\hline & & キレート法 & 金属のキレート錯体を利用 & $\mathrm{PbS}, \mathrm{ZnS}$ \\
\hline & & 化合物分解析出法 & 金属の化合物の分解反応を利用 & $\mathrm{CdS}, \alpha-\mathrm{Fe}_{2} \mathrm{O}_{3}$ \\
\hline & & 貧溶媒希釈法 & 溶液に貧溶媒を添加し析出 & $\mathrm{S}$ \\
\hline & \multirow{4}{*}{ 不均一系 } & $\begin{array}{r}\text { マイクロエマルジョン法 } \\
\text { (液－液） }\end{array}$ & $\begin{array}{l}\text { 金属塩水溶液のマイクロエマルジ } \\
\text { ョンを還元 }\end{array}$ & $\mathrm{Rh}, \mathrm{Pd}, \mathrm{Ir}, \mathrm{Pt}$ \\
\hline & & 乳化重合法 （液－液） & $\begin{array}{l}\text { エマルジョン中でモノマーのミセ } \\
\text { ルをポリマー化 }\end{array}$ & ポリスチレン \\
\hline & & シード重合法（固－液） & $\begin{array}{l}\text { 生成過程を核形成と成長に } 2 \text { 分す } \\
\text { る。大サイズのあのあ合成可能 }\end{array}$ & ポリスチレン \\
\hline & & 相＼cjkstart変 化 法(固－液) & $\begin{array}{l}\text { 一度析出する相を相変化して別の } \\
\text { 結晶相とする }\end{array}$ & $\alpha-\mathrm{Fe}_{2} \mathrm{O}_{3}, \mathrm{Co}_{3} \mathrm{O}_{4}$ \\
\hline
\end{tabular}


述するように，粒子を液中に分散して重力沈降によっ て粒子を密充填に整列させる場合には $\sigma_{\mathrm{g}}$ が 1.05 程度以 下になることが必要なようである。

単分散粒子の一般的合成法についてま之めてみたの が, 表 1 である。液相からでは均一系と不均一系とが あり, 有機物の単分散粒子は不均一で合成される。無 機物はほとんどが均一系である。

\section{3. 金属アルコキシド2)}

金属アルコキシドは一般式 $\mathrm{M}(\mathrm{OR}) \mathrm{n}$ で, $\mathrm{M}$ は金属, $\mathrm{R}$ はアルキル基である。アルコキシドをアルコールの 誘導体とみることもできるし, 金属水酸化物 $\mathrm{M}(\mathrm{OH})_{\mathrm{n}}$ の水酸基の水素をアルキル基に置換したとも考えられ る。

アルコキシドの性質は中心金属原子の性質とアルキ ル基の分子の形と性質によって決まる。例えば $\mathrm{M}(\mathrm{OR}) \mathrm{n}$ の R基の炭素数が増加するにつれて沸点が高くなり， 揮発しにくくなる。

アルコキシドの水との反応は一般に非常に速いが, 遅いあのもある。例えばケイ素のアルコキシド( $\mathrm{Si}$ $\left(\mathrm{OC}_{2} \mathrm{H}_{5}\right)_{4}$ など) 媒を用いて反応を高めるてとが必要となる。水と反 応すると加水分解し, 水酸化物を生成する。乙の際 の加水分解に及ぼす重要な因子としては

(1)水/アルコキシド比……加水分解の重合の程度や 生成する分子種の性質

(2)アルコキシドおよび水を両者の共通溶媒による希 釈……反応速度や生成物の重合度

(3)温度……反応速度, 生成物の種類や結晶性 などが挙げられる。

あう一つアルコキシドで重要なのはアルコキシドの 複合化である。例えば<smiles>[R]O[Si]([R])(O[R20])O[R]O[18OH]</smiles><smiles>[R]O[Z]([R7])([R])O[Si]([R7])([R])O[R2]</smiles>

のようにケイ素とジルコニウムを組み込んだアルコキ シドが生成する。乙の場合, アルキル基 $\left(\mathrm{R}, \mathrm{R}^{\prime}\right)$ が異 なっているが, 同一であ構わない。乙れを複合アルコ キシドと称している。てのようなアルコキシドでは 2 種の金属元素が分子のオーダーで混合しているので, 組成の均一性が保たれるととが予想される。アルコキ
シドを複合化させるのに還流(Refluxing)の方法がよく用 いられる。乙れは図 3のような簡単な装置で数〜十数時 間還流をするあので, 水分などが系に入らないように乾 燥 $\mathrm{N}_{2}$ ガスを流す。このような方法で実際に複合アル コキシドが生成したという確実な知見はほとんどない。 例えば 2 種のアルコキシドのうち一方は溶媒にとける が, 他方は固定で単独では溶媒に溶けない場合, 両者 を混ぜて還流すると固体が溶ける。てのような現象は 複合アルコキシドの生成によると考えられている。

さて, 次は加水分解である。アルコキシドはアルコー ルに溶解する。乙の際の溶媒であるアルコール中の水分 量は後の工程に大きな影響を与えるので, あらかじめア ルコール中の水分は $100 \mathrm{ppm}$ 以下にするてとが大切で ある。アルコール中の水分の除去は生石灰による方法 や金属マグネシウムをアルコキシドにし，さらに加水 分解により脱水する方法などがあるが，モレキュラー シーブによる脱水法が便利である。また水分量の測定 にはカール・フィッシャー法が用いられ, 市販装置で は数分間で ppmオーダーの量が測定できる。

アルコキシドは合成するてともできるし，また最近 は市販品も多品種になり, 場合によっては合成を受付 ける試薬品メーカーあある。市販品の場合, 各メーカ 一によって品質が異なる。一般に純度は金属元素だけ そついてであって，アルキル基の種類は全く関係ない。 そてで, 必ずしあアルキル基が一種類だけとあ限らず, またアルコキシドがどの程度重合しているかは現在の ところ分析されていない。単量体は少なく，2量体や 3 量体が多いといわれている。乙のような重合程度の 相異が, 薬品メーカーによって同一のアルコキシドが 液体になったり固体となったりする事実に相応してい ると考えている。また, アルコキシド試楽中の金属含 有量を示性式から求めるのは危険で, 改めて分析し直 す方がよい。

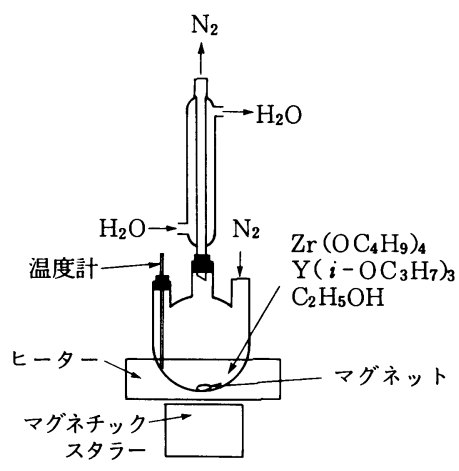

因 3 還流装置 
アルコキシドは金属とアルコールの直接反応によっ て作られるが，比較的活性でない金属ではナトリウム アルコキシドのナトリウムを金属で置換する方法が用 いられる。乙の時, 液中に水酸化ナトリウムなどが残 留することがある。このようなアルコキシドをアルコ ールに溶かした時, 液が強いアルカリ性を示すことが ある。注意を要することである。

脱水したアルコールや一般のアルコキシドは吸湿性 が非常に強い。そのため, 試薬の保存や試料溶液の調 製などには乾燥需囲気のグローブボックスの使用が望ま しい。

アルコールの種類の選択はまず第 1 にアルコキシド のアルキル基と同一の基をあつアルコールが望ましい。 また，乙の組み合わせの場合が固体アルコキシドを最 あよく溶解するアルコールのようである。しかし，溶 解するアルコールが見付からない時は 2 種のアルコー ルの混合液を用いると成功することもある。

\section{4. アルコキシドの加水分解 ${ }^{3 \sim 9 !}$}

アルコキシドのアルコール溶液と水のアルコール溶 液を混合するてとによって加水分解反応が進行する。 図 4 はこれを模式的に示したあのである。我々の場合 には水をアルコキシド溶液に滴下させているが，スタ ーラーで液を擋拌しながら $100 \mathrm{ml}$ を十数秒で滴下す る。条件にもよるが, 全液滴下を終了しても透明な液 体である。数分間から数時間の間に液が乳白色になる。 乙の滴下後から乳白色になるまでの時間(Opalesence時 間）と生成粒子の形態の関係を図 5 亿示した。乙のよ うに，粒子の生成が速すぎると，多分散になりやすい。 また, 極端に遅い場合も同様である。そして, 場合に よっては粒径分布がBimodelになることもある。

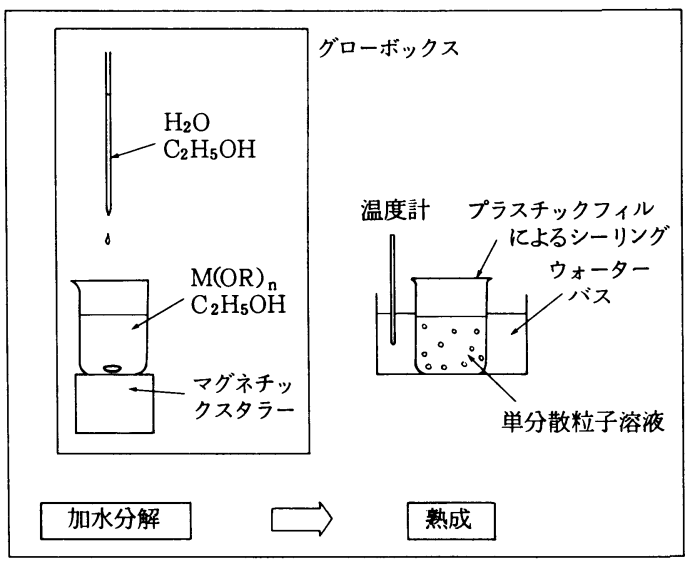

図4 アルコキシド加水分解法

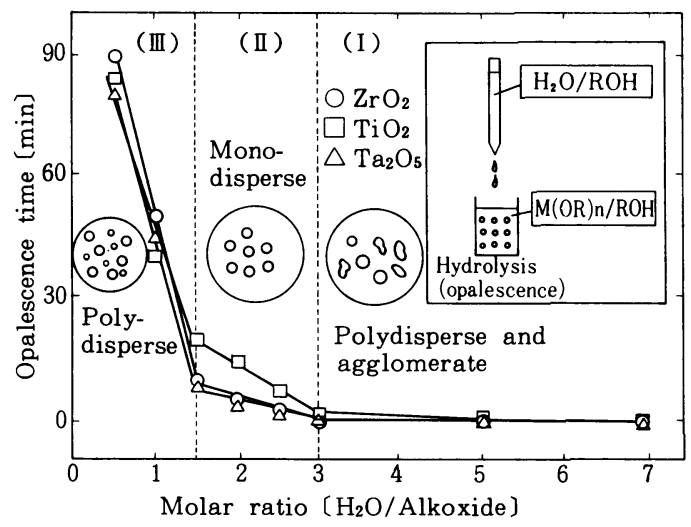

図 $5 \mathrm{H}_{2} \mathrm{O} /$ アルコキシド濃度比が加水分解速度や生成粒子形態 に及ぼす影䈏

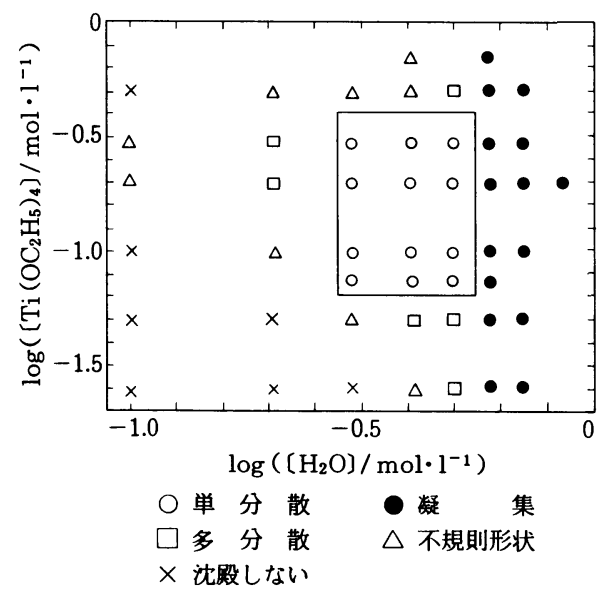

図 6 アルコキシドと水の莀度と生成粒子の形態との関係

このような反応の速さはアルコキシドと水の濃度に 強く影響される。図6はアルコキシドと水の濃度と粒 子の単分散性をしたあので, 非常に限られた条件で単 分散粒子が得られることがわかる。

加水分解後の熟成中における粒子の形態の变化は 図 7 のように時間とともに粒径は増大し，粒径分布 は狭くなる。乙こで，図７の粒径が時間ととあに一定 值に近づくようになる理由の一つは, 粒の生成の増加 につれて溶液中のアルコキシドの濃度が低下して，ア ルコキシドの粒子表面への供給が少なくなるてとと関 連している。事実, 新しい核生成が起てらないように してアルコキシドを追加すると, 再び粒は生長を始め る。

\section{5. 単分散粒子の性質}

得られた粒子は X線的には非晶質である。そして $\mathrm{TiO}_{2}$ や $\mathrm{ZrO}_{2}$ などの粒子はかなりの量の水を含有して 


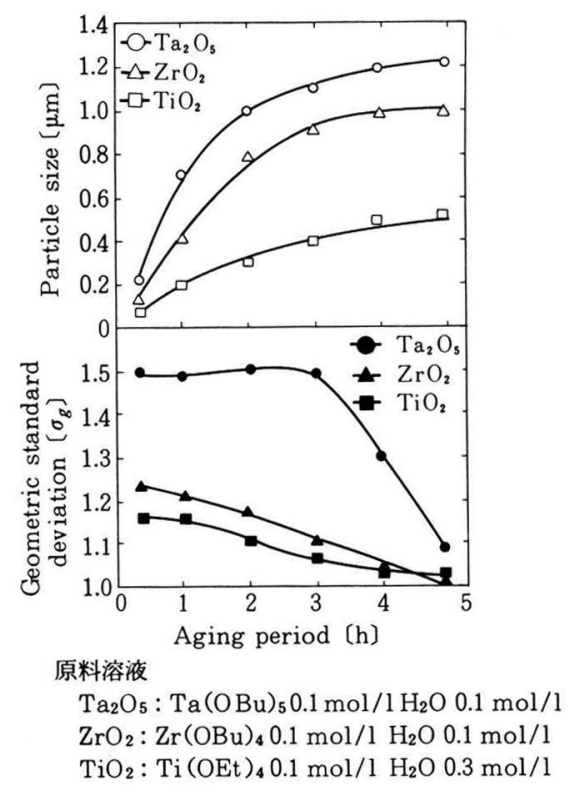

図 7 チタニア, ジルコニア, タンタル酸化物単分散粒子の粒 径や粒径分布の熟成時間に伴う変化 $\left(50^{\circ} \mathrm{C}\right)$

おり，酸化物というより水和物の方に近い。図 8 は熱 分析の一例であるが, 総じて $150^{\circ} \mathrm{C}$ までに水を放出し, $220^{\circ} \mathrm{C}$ 発熱は残留アルコキシドの燃焼による。さら に高温での発熱は非晶質酸化物の結晶化による。

表 2 は単分散粒子の性質をまとめたものである。乙 れらの微粒子を水溶液中に分散して重力沈降させると, 粒子の三次元的配列が観察される。図 9 は $\mathrm{TiO}_{2}$ につい ての写真である。

\section{6. 実用的応用と問題点}

シリカ粒子の単分散を最密充填させ, 時間をかけて
固化させると人工オパールが生成する。このような原 理で日本の数社から人工オパール宝石が販売されてい る。シリカ粒子を蒾科用充填材として用いることが実

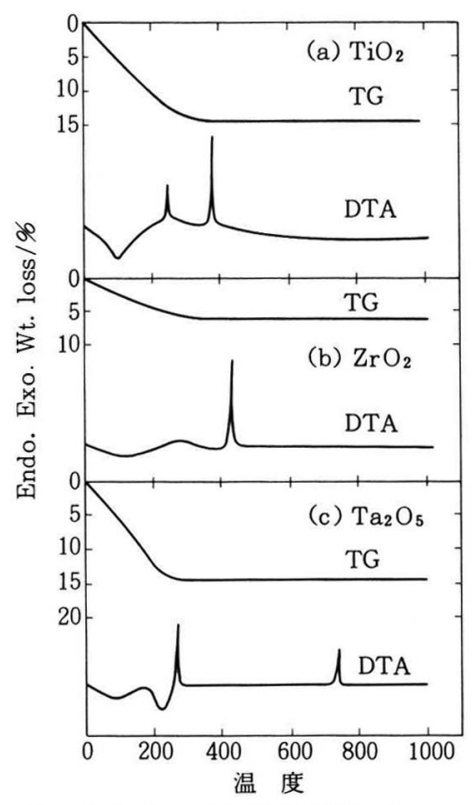

図 $8 \mathrm{TiO}_{2}, \mathrm{ZrO}_{2}$ と $\mathrm{Ta}_{2} \mathrm{O}_{5}$ 単分散粒子の $\mathrm{TG}$ と DTA曲線

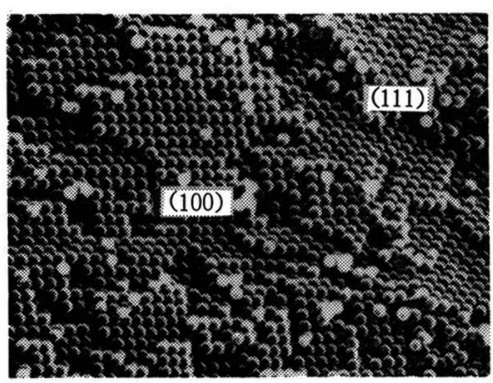

図 $9 \mathrm{TiO}_{2}$ 粒子の重力沈降体の破断面の SEM写真

表 2 単分散微粒子の性質

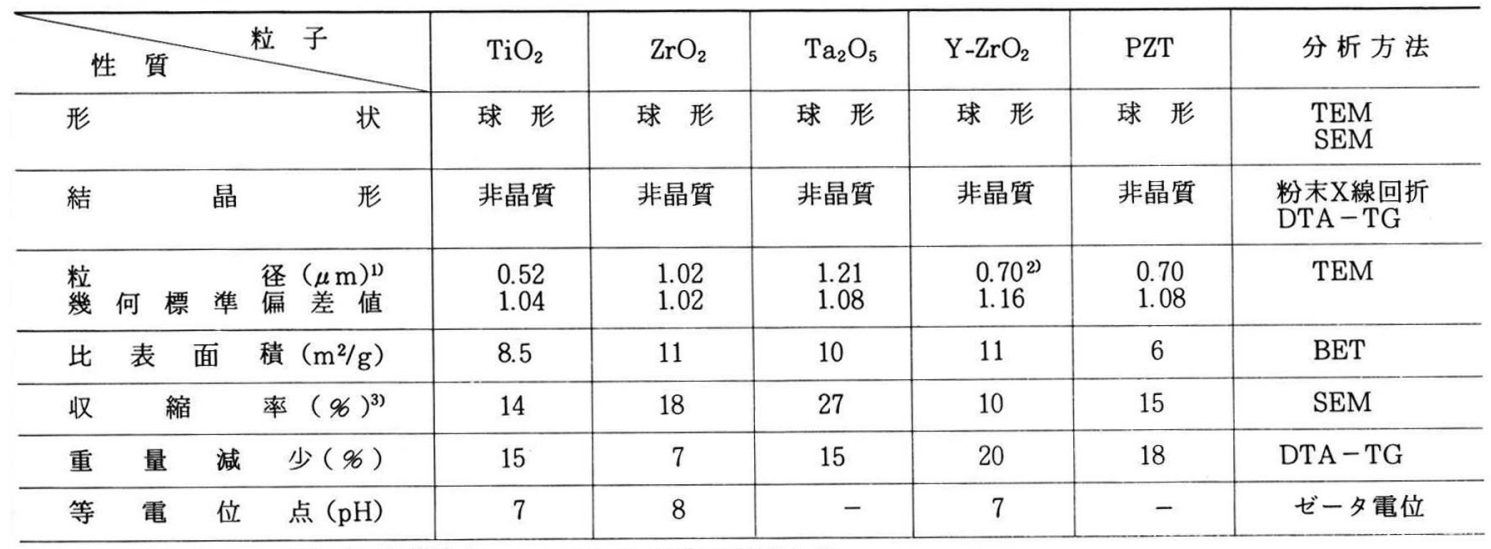

1） 5 時間熟成

2) 10 時間熟成

3) $1000{ }^{\circ} \mathrm{C} 2$ 時間加熱 

(1) 研磨材
(2) 各種フィラー材
(3) スペーサー
(4) カラム充埧材
（5）医療用試薬基材
(6) 各種触媒
(7) 電子顕微鏡標準試料
（8）化精品用基材
（9）歯科材料基材
（10） IC基板焼成用敷粉
(11）分散媒
（12）特殊ガラス混入材
（13）その他

用化されている。悪歯部分を除いた空洞部にシリカを 有機物之ともに充媜するが, 従来は石英粉やエアロゾ ルシリカを使用したが，単分散粒子を用いるとてれら に比べて, 強度, 磨耗, 耐久性, 色調などの点で優れ ている。液晶のスペーサーや電顕用の標準球に用いる 計画あある。表 3 はシリカ単分散粒子のカタログから とったあのである。てれらいずれも今後の発展が期待 される分野であろう。

応用上の問題点としては, 性質上では, 単分散球の 多くがアモルファスで含水物であることが挙げられる。 特に含水物は加熱すると水蒸気を放出し, 収縮したり,
粒子の凝集を起乙し，本来の真球や単分散性が失われ ることがある。アモルファスはシリカのように高温ま でその状態であるあのは良いが, 多くの場合は低温で 結晶化し, 形が変化する。

製造上では高価なアルコキシドが原料になる。溶媒 としてのアルコールが多量に必要となる。バッチ式の 製法になり易く，連続法が困難である。乙れらのてと はセラミックスの原料製造では必ずしも特別なことで はないが、コスト低減には大切な課題となる。

\section{7.おわりに}

単分散粒子で現在実用化されているのはシリカ粒子 である。人工オパールの合成や歯科材料, あるいはス ペーサーとしての用途である。しかし，いずれあ多量 に用いられてはいない。セラミックス焼結体への応用 は検討中の状態である。単分散粒子を乾粉にして成形 する方法よりあ，スラリーのまま，膜形成や鋳込み成 形などへ利用する方法が将来, 実用上む有利だと考え られる。

\section{引 用 文 献}

1) 水谷, 木村, 尾崎, 山口著「セラミックプロセシング」 p. 23 技報堂(1985)

2 ) Bradley, D. C., R. C. Mehrotra, D. P. Gaur "Metal Alkoxides" Academic Press (1978)

3 ) 池本, 植松, 水谷, 加藤: 窯協誌, 93, 261 (1985) $\left(\mathrm{TiO}_{2}\right.$ 粒子)

4) Ikemoto, T., N. Mizutani, M. Kato, and Y. Mitarai : 䀄協誌, 93, 585 (1985) $\left(\mathrm{ZrO}_{2}\right.$ 粒子)

5) Ogihara, T., T. Ikemoto, N. Mizutani and M. Kato: J. Mat.Sci., 21, 2771 (1986)

$\left(\mathrm{Ta}_{2} \mathrm{O}_{5}\right.$ 粒子)
6) Ogihara, T., N. Mizutani and M. Kato: Ceram. Inter., 13, 35 (1987)

$\left(\mathrm{ZrO}_{2}\right.$ 粒子)

7 ) Uchiyama, K., T. Ogihara, N. Mizutani and M. Kato: J. Mat.Sci., 22, 4343 (1987)

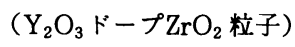

8) Ogihara, T., M. Kaneko, N. Mizutani, and M. Kato: J. Mat.Sci.Letter, 7, 867 (1988) (PZT 粒子)

9) Ogihara, T., N. Mizutani and M. Kato: J. Am. Ceram.Soc., 72, 印刷中 (1989)

(粒成長) 